\title{
ACID-BASE STRENGTHS IN PYRIDINE
}

\author{
M. BOS AND E. A. M. F. DAHMEN
}

Depurtment of Chemicul Technology. Twente Unitersity of Techmology. Enschede (The Netherlunds) (Reccived July 21s1. 1970)

Pyridine is an important solvent for acid-base titrations, but there are few systematic investigations about the equilibria that play a part in neutralization reactions in pyridine. It is generally accepted that ion pairs occur as intermediates in the dissociation of acids in solvents like pyridine ${ }^{1-3}$. Only overall dissociation constants of some acids have been measured in pyridine ${ }^{1.2}$.

When ion-pair formation occurs these overall dissociation constants are not suitable for the comparison of the acid strengths of a compound in different solvents ${ }^{4}$. For this comparison the so-called ionization constants are needed. If the dissociation of an acid in pyridine is represented by the following equilibria

$$
\mathrm{HX} \leftrightharpoons \mathrm{H}^{+} \mathrm{X}^{-}=\mathrm{H}^{+}+\mathrm{X}^{-}
$$

this ionization constant is defined as

$$
K_{i}^{\prime \prime X}=\left[\mathrm{H}^{+} \mathrm{X}^{-}\right] /[\mathrm{HX}]
$$

The dissociation constant of the ion pair is given by

$$
K_{d}^{H \cdot X^{-}}=\left[\mathrm{H}^{+}\right]\left[\mathrm{X}^{-}\right] /\left[\mathrm{H}^{+} \mathrm{X}^{-}\right]
$$

For acids of the ammonium type the dissociation can be represented by

$$
\mathrm{BH}^{+}=\mathrm{B}+\mathrm{H}^{+}
$$

Here the dissociation constant can be defined as

$$
\mathrm{Ka}_{\mathrm{d}}^{\mathrm{BH}+}=[\mathrm{B}]\left[\mathrm{H}^{+}\right] /\left[\mathrm{BH}^{+}\right]
$$

In order to determine the ionization constant of an indicator acid, the method proposed by Kolthoff and Bruckenstein ${ }^{4}$ can be used.

In this paper, besides the application of the method by Kolthoff and Bruckenstein, a method for the determination of dissociation constants of acids of the ammonium type from titration curves is discussed.

\section{EXPERIMENTAL}

Chemicals

Pyridine. Pyridine (Merck, reagent grade) was kept over an activated molecular sieve $3 \mathrm{~A}$ for $48 \mathrm{~h}$ and was afterwards distilled over barium oxide. The pyridine (b.p. $115^{\circ}$ ) was collected and stored in an automatic burette. From this burette it was 
dispensed under pressure of carbon dioxide-free nitrogen. The water content was below $0.05 \%$ (Karl Fischer titration).

Perchloric acid. This was used as its pyridinium salt, which was prepared as described by Mukherjec et al. ${ }^{2}$.

Hydrochloric acid. Solutions of hydrochloric acid in pyridine were prepared by passing a stream of dry hydrogen chloride gas through pyridine.

Sulfomphthalein.s. The sulfon ph tha leins, bromophenolblue, bromocresol purple, bromocresol green and chlorophenol red (indicator grade, Merck) were used as received.

Nitrophenols. The following samples were used : picric acid (Merck, reagent grade), 3-nitrophenol (Merck, indicator grade), 2,4-dinitrophenol (Merck and dried in vacuo at 40 ), 2.5-dinitrophenol (Merck, indicator grade), 2,6-dinitrophenol (Merck, indicator grade). All the dinitrophenols were recrystallized twice from ether and dried in vacuo at $40^{\circ}$.

Bases. The bases used were n-butylamine, triethylamine and morpholine, all of which were reagent grade (Fluka).

Spectrophotometric technique

All measurements were carricd out with a Zeiss spectrophotometer, type PMQ II, at a temperature of $20 \pm 2^{\circ}$ in quartz cells with a light path of $1 \mathrm{~cm}$.

\section{Differential vapour pressure measurements}

A Mechrolab model $301 \mathrm{~A}$ osmometer was used for the differential vapour pressure measurements at $37^{\circ}$. The osmometer was calibrated for pyridine with benzil.

\section{Potentionetric mectsurements}

A Knick pH-meter, type 260, was used for the potentiometric measurements. The glass electrode was a Radiometer G222c electrode. As reference clectrode an $\mathrm{Ag} / \mathrm{AgCl}$ clectrode filled with a saturated solution of tetramethylammonium chloride in pyridine was used. When not in use the glass electrode was kept in an aqueous buffer $\mathrm{pH}$ of 7 . With this set of electrodes each potential measurement was continued until its change within $5 \mathrm{~min}$ became less than $2 \mathrm{mV}$. This took about $30 \mathrm{~min}$. The resulting values are reproducible within $\pm 2 \mathrm{mV}$. The glass electrode was calibrated regularly in standard solutions of perchloric acid in pyridine.

\section{Potentiometric titrations}

The potentiometric titrations were recorded automatically with a Radiometer titration assembly composed of pH-meter PHM 28, burette ABU 2, recorder SBRC, and titrator TT 11. The electrode set was the same as the one described above. Titration curves were reproducible within $\pm 5 \mathrm{mV}$.

RESUL'TS

\section{Spectrophotometric mecisurements}

If an ion pair occurs as an intermediate in the dissociation of an indicator acid, the ionization and dissociation constant of this acid can be determined spectro- 
photometrically by means of the method developed by Kolthoff and Bruckenstein ${ }^{2}$. This method is based on the equation

$$
[\mathrm{HIn}] /\left\{\Sigma[\text { base }]-K_{\mathrm{i}}[\mathrm{HI}]\right\}^{2}=\left(K_{\mathrm{i}} K_{\mathrm{d}}\right)^{-1}
$$

where [HIn] is the concentration of the indicator in the acid colour, and $\Sigma$ [base] is the spectrophotometrically determined concentration of the indicator in the basic colour; $K_{1}$ and $K_{d}$ are the ionization and the dissociation constants, respectively.

In the case of the polynitrophenols and sulfonphthaleins application of ecjn. (6) did not result in a single value for $K_{i}$. Instcad, the results of the experiments, plotted according to eqn. (6) gave straight lines for a wide range of values for $K_{1}$. The results did, however, follow the equation for simple dissociation :

$$
\{\Sigma[\text { base }]\}^{2} /[\mathrm{HIn}]^{1}=K_{11 x}
$$

For the determination of the dissociation constants of sulfonphthaleins, solutions of these compounds were used in which the first step of the acid was neutralized with tetramethylguanidine. Molar extinction coefficients were determined in solutions of the indicators to which an excess of tetramet hy latm monium hydroxide had been added.

The dissociation constants calculated from ecpn. (7) are given in Table 1.

TABLE I

\begin{tabular}{|c|c|c|c|c|}
\hline Indicater & $i_{\text {mat rnore }}(m m)$ & limere & KN.X & $p K_{\| x}$ \\
\hline Picric acid & 380 & $1.91 \cdot 10^{+4 h}$ & $1.1 \cdot 10 \cdot 1$ & 3.0 \\
\hline 2,6-Dinitrophenol & 462 & $1.07 \cdot 10^{4 n}$ & $5.9 \cdot 10^{-5}$ & 4.2 \\
\hline 2.5-Dinitrophenol & 470 & $5.77 \cdot 10^{.16}$ & $9.8 \cdot 10^{-0}$ & 5.0 \\
\hline Bromophenol bluc ${ }^{2}$ & 607 & $1.17 \cdot 10^{5}$ & $5.6 \cdot 10^{-2}$ & 5.3 \\
\hline Bromocresol green 2 & 63.3 & $6.59 \cdot 10^{4}$ & $3.4 \cdot 10^{*}$ & 5.5 \\
\hline Bromocresol purple 2 & 610 & $1.09 \cdot 10^{5}$ & $3.1 \cdot 10^{-n}$ & 7.5 \\
\hline Chlorophenol red² & 597 & $8.03 \cdot 10^{2}$ & $8.4 \cdot 10 \% 11$ & 10.1 \\
\hline
\end{tabular}

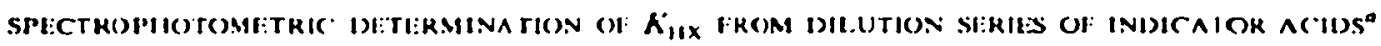

"Activity coefficients for ionic specics were calculatcd from $-\log \int=8.191 \mu^{4}$. while the alctivity cocflicients for non-ionic species were assumed to be unity.

"It was assumed that the acid is non-ibsorbing at this wavelength.

\section{Differential vapour pressure measurements}

The overall dissociation constant of an acid $\mathrm{HX}$ can be found by means of differential vapour pressure (DVP) measurements with the equation'

$$
K_{11 X}=\left(m_{\mathrm{d}}-m_{\mathrm{s}}\right)^{2} /\left(2 m_{\mathrm{s}}-m_{\mathrm{d}}\right)
$$

. where $m_{\mathrm{d}}$ is the molarity measured by the DVP method and $m_{\text {, is }}$ the stoichiometric concentration of $\mathrm{HX}$.

The same cquation can be applied in the determination of the dissociation constant of salts by this method (assuming that no acid-base dissociation occurs). (salts).

The results of the DVP measurements are given in Table II (acids) and Table III

Anal. Chim. Acta. 53 (1971) 39-46 
TABLE II

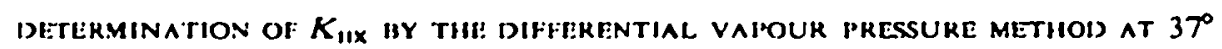

\begin{tabular}{lll}
\hline Acid & $K_{11 x}$ & $r K_{11 x}$ \\
\hline Perchloric acid & $9.3 \cdot 10^{-4}$ & 3.0 \\
Picric acid & $1.3 \cdot 10^{-3}$ & 2.9 \\
2.5-Dinitrophenol & $2.8 \cdot 10^{-9}$ & 4.6 \\
2.6-Dinitrophenol & $2.1 \cdot 10^{-4}$ & 3.7 \\
2.4-Dinitrophenol & $1.0 \cdot 10^{-4}$ & 4.0 \\
\hline
\end{tabular}

TABLE III

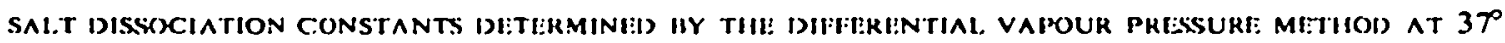

\begin{tabular}{|c|c|c|c|c|}
\hline & $\begin{array}{l}\text { Toetres- } \\
\text { methyl- } \\
\text { guanidine }\end{array}$ & $\begin{array}{l}n-B u a y l- \\
\text { comince }\end{array}$ & $\begin{array}{l}\text { Morpho- } \\
\text { linc }\end{array}$ & $\begin{array}{l}\text { Triethyl- } \\
\text { amine }\end{array}$ \\
\hline $\begin{array}{l}\text { Perchloric acid } \\
\text { Hydrochloric acid } \\
\text { Picric acid } \\
\text { 2.5-Dinitrophenol } \\
\text { 2.6-Dinitrophenol } \\
\text { 2.4-Dinitrophenol }\end{array}$ & $\begin{array}{l}1.5 \cdot 10^{-3} \\
1.5 \cdot 10^{-4} \\
3.9 \cdot 10^{-4} \\
2.6 \cdot 10^{-4} \\
4.0 \cdot 10^{-4} \\
5.2 \cdot 10^{-4}\end{array}$ & $\begin{array}{l}9.5 \cdot 10^{-4} \\
6.3 \cdot 10^{-4} \\
6.7 \cdot 10^{-4}\end{array}$ & $\begin{array}{l}6.1 \cdot 10^{-3} \\
3.4 \cdot 10^{-3} \\
2.0 \cdot 10^{-3}\end{array}$ & $\begin{array}{l}5.3 \cdot 10^{-4} \\
2.8 \cdot 10^{-6} \\
1.6 \cdot 10^{-3}\end{array}$ \\
\hline
\end{tabular}

Potentiometric measurements. Calibration of the glass electrode At $25^{\circ}$ the c.m.f. of the cell glass electrode / solution $\mathrm{HX}$ | ref. electrode is given by

$$
E_{(\mathrm{mv})}=E_{\mathrm{ref}}+E_{\mathrm{l}, \mathrm{J}}+29.5 \log K_{11 \mathrm{x}}+29.5 \log C_{11 \mathrm{x}}
$$

By measuring an acid with a known overall dissociation constant, one can find $E_{\mathrm{rer}}+E_{1, \mathrm{~J} .}$. If it is assumed that $E_{\mathrm{rer}}+E_{1, \mathrm{j}}$ is constant, one can detcrmine $\mathrm{pH}$ values of unknown solutions from

$$
\mathrm{pH}=\frac{1}{39}\left(E_{\mathrm{rer}}+E_{\mathrm{l} . \mathrm{j} .}-E\right)
$$

The behaviour of the glass electrode used can be represented by

$$
E_{(m v)}=29.4 \log C_{1 \mathrm{ClO}_{4}}+155
$$

or, with $\mathrm{p} K_{\mathrm{HClO}_{4}}=3.2^{1}$ :

$$
E_{(m v)}=250+59 \log \left[\mathrm{H}^{+}\right]
$$

This calibration with perchloric acid solutions was repeated for each set of potentiometric determinations. The results of the potentiometric determinations, calculated according to the equation for simple dissociation, are given in Table IV.

Anal. Chim. Acta. 53 (1971) 39-46 
TABLE IV

K IIX. DETERMINED POTENTIOMETHICALLY

\begin{tabular}{llc}
\hline Acid & $\mathcal{K}_{\| x}$ & $p K_{11 x}$ \\
\hline Picric acid & $2.8 \cdot 10^{-1}$ & 3.5 \\
2,6-Dinitrophenol & $1.9 \cdot 10^{-3}$ & 4.7 \\
2,5-Dinitrophenol & $5.1 \cdot 10^{-8}$ & 5.3 \\
3-Nitrophenol & $1.4 \cdot 10^{-13}$ & 12.5 \\
2,4-Dinitrophenol & $4.1 \cdot 10^{-9}$ & 4.4 \\
\hline
\end{tabular}

\section{Potentiometric titrations}

The following equilibria can be assumed to play a part in the titration of an acid $H X$ with a nitrogen base $B$ :

$$
\begin{aligned}
& \mathrm{HX} \stackrel{\kappa_{\text {lax }}}{=} \mathrm{H}^{+}+\mathrm{X}^{-} \\
& \mathrm{H}^{+}+\mathrm{B} \stackrel{1 / K_{?}^{\prime \prime \prime}}{=} \mathrm{BH}^{+} \\
& \mathrm{BH}^{+}+\mathrm{X}^{-} \stackrel{1 / K_{a}^{\prime \prime \prime}}{=} \mathrm{BH}^{+} \mathrm{X}^{-}
\end{aligned}
$$

If the equilibrium constants are known, the titration curve can be calculated by general methods of equilibrium calculations ${ }^{5}$ with the aid of a fast digital computer. On the other hand equilibrium constants can be calculated from experimental titration curves by repeatedly entering the calculation procedure with various values for the constant to be determined until for one value of this constant, the experimental and the calculation curves give the best fit. In this way, the value of $K_{d}^{n !}$ for nitrogen bases can be determined when they are titrated with an acid of a known dissociation constant.

With the dissociation constants of the salts measured by the DVP method, $K_{d}^{-\mathbf{p H}^{*}}$ values were determined for tetramethylguanidine- $\mathrm{H}^{+}$. morpholine- $\mathrm{H}^{+}$. triethylamine- $\mathrm{H}^{+}$and $n$-butylamine- $\mathrm{H}^{+}$from the titrations of hydrochloric acid, perchloric acid and picric acid with the corresponding bases. The following $p K$ values were used for the acids in the calculations: $p K_{1 \mathrm{HCl}}=5.66^{1}, \mathrm{p} K_{1 \mathrm{HClO}}=3.2^{\prime}$, $p K_{\text {pleric acld }}=3.0$. The results a re summarized in Table $V$.

If homoconjugation does occur, the following set of equilibria must be used in the calculations:

\begin{tabular}{|c|c|c|c|c|}
\hline \multirow[t]{2}{*}{ Acid used } & \multicolumn{4}{|l|}{$K_{g}^{A \prime \prime}$} \\
\hline & n-Butylamine & Morpholine & Triethylamine & $T M G$ \\
\hline $\begin{array}{l}\text { Perchloric acid } \\
\text { Picric acid } \\
\text { Hydrochloric acid }\end{array}$ & $\begin{array}{l}1.7 \cdot 10^{-6} \\
6.0 \cdot 10^{-6} \\
2.5 \cdot 10^{-6}\end{array}$ & $\begin{array}{l}2.9 \cdot 10^{-4} \\
5.0 \cdot 10^{-4} \\
1.5 \cdot 10^{-4}\end{array}$ & $\begin{array}{l}2.0 \cdot 10^{-4} \\
1.3 \cdot 10^{-4}\end{array}$ & $\begin{array}{l}4.2 \cdot 10^{-10} \\
1.0 \cdot 10^{-10} \\
2.1 \cdot 10^{-10}\end{array}$ \\
\hline Average & $3.5 \cdot 10^{-6}$ & $3.1 \cdot 10^{-4}$ & $1.7 \cdot 10^{-4}$ & $2.4 \cdot 10^{-10}$ \\
\hline
\end{tabular}

TABLE $V$

KdII DETERMINIS FROM POTENTHOMETRIC TITRATIONS 


$$
\begin{aligned}
& \mathrm{HX} \stackrel{N_{\text {IIX }}}{=} \mathrm{H}^{+}+\mathrm{X}^{-} \\
& \mathrm{HX}+\mathrm{X}^{-\stackrel{\kappa_{11 X_{1}}}{=}} \mathrm{HX}_{2}^{-} \\
& \mathrm{B}+\mathrm{H}^{+} \stackrel{1 / \mathrm{K}_{1.11}^{111 \cdot}}{=} \mathrm{BH} \mathrm{H}^{+} \\
& \mathrm{BH}+\mathrm{X}^{-} \stackrel{1 /{\mathrm{K} ; \mathbf{i}^{11}}}{=} \mathrm{BH} \mathrm{H}^{+}
\end{aligned}
$$

With known values for $K_{d}^{\text {ult }}$ and $K_{d}^{B \prime \prime}$, the dissociation constant, $K_{11 x}$, as well as the homoconjugation constant, $K_{11 x_{2}}$, can be determined from the curves of the potentiometric titrations of 2,4-dinitrophenol, 2,5-dinitrophenol and 2,6-dinitrophenol with tetramethylguanidine. Here, it is necessary to vary both $K_{11 x}$ and $K_{11 x_{2}}$ until the best fit between experimental and calculated titration curve occurs. The results of these determinations arc summarized in Table VI.

I)ISC:USSION

The results of the spectrophotometric determinations of the dissociation constants of polynitrophenols and sulfonphthaleins can be explained on the basis of

TABLE VI

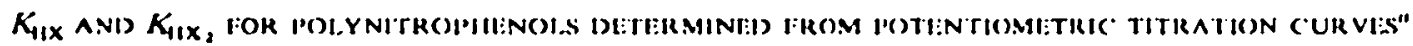

\begin{tabular}{llc} 
Compound & $K_{11 x}$ & $K_{11 x_{3}}$ \\
\hline 2.4-Dinitrophenol & $5 \cdot 10^{-3}$ & 10 \\
2.5-Dinitrophenol & $2.8 \cdot 10^{-7}$ & 100 \\
2.6-Dinitrophenol & $1.1 \cdot 10^{-3}$ & $10^{-1}$
\end{tabular}

\begin{tabular}{|c|c|c|c|c|}
\hline \multirow[t]{2}{*}{ Compenund } & \multicolumn{4}{|l|}{$p K$} \\
\hline & Spectrophestom. & $D V P$ & Polcintiom. & Titrution \\
\hline Picric acid & 3.0 & 2.9 & 3.5 & \\
\hline 2.6-Dinitrophenol & 4.2 & 3.7 & 4.8 & 4.7 \\
\hline 2.4-Dinitrophenol & & 4.0 & 4.4 & 4.3 \\
\hline 2.5-Dinitrophenol & 5.0 & 4.6 & 5.3 & 6.5 \\
\hline Bromoplicnol bluc ${ }^{2}$ & 5.3 & & & \\
\hline Bromocresol purple 2 & 7.5 & & & \\
\hline Bromocresol green ${ }^{2}$ & 5.5 & & & \\
\hline Chlorophenol red ${ }^{2}$ & 10.1 & $\cdot$ & & \\
\hline 3-Nitrophenol & & & 12.5 & \\
\hline "B-Butylamine- $\mathrm{H}$ + & & & & 5.5 \\
\hline Morpholinc-1+ ${ }^{+}$ & & & & 3.5 \\
\hline Tricthylaminc- $\mathrm{H}^{+}$ & & & & 3.8 \\
\hline Tetramethylguanidine $\cdot \mathrm{H}^{+}$ & & & & 9.6 \\
\hline
\end{tabular}

"Calculations based on concentrations. not on activitics.

Tヘ131.E VII

pK VAI.UISS IN I'YKIDINI: 
simple dissociation. This indicates that no ion pairs occur as intermediates in the dissociation of these compounds in pyridine, although the dielectric constant of this solvent is rather low.

Homoconjugation can explain the typical form of the curves for the titrations of 2,4-dinitrophenol, 2.5-dinitrophenol and 2,6-dinitrophenol with tetramethylguanidine. It also explains the discrepancies in the $\mathrm{p} K$ values determined from the titration curves on the one hand and from spectrophotometric and potentiometric measurements on the other, for the latter are calculated on the basis of simple dissociation only.

The differences found by Mukherjee et $a{ }^{1}{ }^{1}$ between $\mathrm{p} K$ values determined spectrophotometrically in solutions of pure 2,5-dinitrophenol and in mixtures of 2.5-dinitrophenol and a non-absorbing acid can be explained in the same way.

The $p K$ values, determined in different ways, are summarized in Table VIl. A comparison of the $p K$ values in water and in pyridine is given in Table VIII.

TABLE VIII

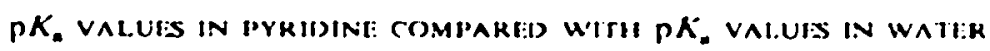

\begin{tabular}{|c|c|c|c|}
\hline Compoumd & $p K_{\text {(pre) }}$ & $p K_{\text {(nater) }}$ & $\Delta P K$ \\
\hline Picric acid & 3.0 & 0.4 & 2.0 \\
\hline 2.6-Dinitrophenol & 3.7 & 3.0 & 0.7 \\
\hline 2.4-Dinitrophenol & 4.2 & 3.5 & 0.7 \\
\hline 2.5-Dinitrophenol & 5.0 & 4.7 & 0.3 \\
\hline Bromophenol bluc ${ }^{2}$ & 5.3 & 4.0 & 1.3 \\
\hline Bromocresol green ${ }^{2}$ & 5.5 & 4.7 & 0.6 \\
\hline Bromocresol purple ${ }^{2}$ & 7.5 & 6.1 & 1.4 \\
\hline Chlorophenol red ${ }^{2}$ & 10.1 & 6.1 & 4.0 \\
\hline 3-Nitrophenol & 12.5 & 7.2 & 5.3 \\
\hline "I-Butylamine-H* & 5.5 & 10.6 & -5.1 \\
\hline Morpholine-H & 3.5 & 9.6 & -6.1 \\
\hline Tricthylaminc- $\mathrm{H}^{*}$ & 3.8 & 10.8 & -7.0 \\
\hline Tetramethylguanidinc- $\mathrm{H}^{+}$ & 9.6 & 12.3 & -2.7 \\
\hline
\end{tabular}

It is interesting to note that the $p K$ values for the protonated nitrogen bases are much lower in pyridine than in water. Undoubtedly, this is due to the greater basicity of pyridine compared with water. With uncharged or negatively charged acids the dielectric constant of the solvent has great influence on the dissociation. This could explain why for these acids $p K_{\text {(pyridine) }}$ is greater than $p K_{\text {(water). }}$

The authors wish to thank Mr. H. Hof who carried out most of the potentiometric determinations and Miss A. L. Dekkers who prepared the manuscript.

SUMMARY

Although pyridine is a solvent with a low dielectric constant, spectrophotoAnal. Chim. Acla. 53 (1971) 39-46 
metric determinations show simple dissociation without ion pairs as intermediates for some sulfonphthaleins and polynitrophenols in pyridine.

The salts of a number of amines and hydrochloric acid, perchloric acid and picric acid are not completely dissociated in pyridine. Dissociation constants of these salts were determined from differential vapour pressure measurements. For the titrations in pyridine of an acid with an amine, calculations were based on the following reactions: $\mathrm{HX} \leftrightharpoons \mathrm{H}^{+}+\mathrm{X}^{-} ; \mathrm{B}+\mathrm{H}^{+} \leftrightharpoons \mathrm{BH}^{+} ; \mathrm{BH}^{+}+\mathrm{X}^{-} \leftrightharpoons \mathrm{BH}^{+} \mathrm{X}^{-}$. With this reaction scheme it was possible to determine $\mathrm{p} K_{\mathrm{a}}$ values for protonated amines in pyridine from the curves of titrations carried out with a calibrated glass electrode. Evidence for the occurrence of homoconjugation of some polynitrophenols in pyridine was found in the titration of these compounds with tetramethylguanidine. Homoconjugation constants were estimated from the titration curves.

RÉSUMÉ

Bien que la pyridine soit un solvant à faible constante dićlectrique, des dosages spectrophotométriques montrent une dissociation simple pour quelques sulfophtaléines et polynitrophénols dans la pyridine. Les sels d'un certain nombre d'amines et acides chlorhydrique, perchlorique et picrique ne sont pas complètement dissociès dans la pyridine. Les constantes de dissociation de ces sels sont déterminécs par des mesures de pression de vapeur différentielle. Pour les titrages d'un acide par une amine, dans la pyridine, des réactions sont données, permettent de déterminer les valeurs de $p K_{n}$.

\section{ZUSAMMENFASSUNG}

Obwohl Pyridin ein Lösungsmittel mit einer niedrigen Dielcktrizitätskonstante ist, weisen spektrophotometrische Untersuchungen einiger Sulfonphthaleine und Polynitrophenole in Pyridin aufeinfache Dissoziation ohne Ionenpaare als Zwischenstufen hin. Die Salze von ciner Anzahl Amine und Salzsäure, Perchlorsäure und Pikrinsäure sind in Pyridin nicht vollständig dissoziiert. Dissoziationskonstanten dieser Salze wurden aus Differentialdampfdruckmessungen bestimmt. Berechnungen für die Titrationen einer Säure mit einem Amin in Pyridin gründ̈eten sich auf folgende Reaktionen: $\mathrm{HX} \leftrightharpoons \mathrm{H}^{+}+\mathrm{X}^{-} ; \mathrm{B}+\mathrm{H}^{+} \leftrightharpoons \mathrm{BH}^{+} ; \mathrm{BH}^{+}+\mathrm{X}^{-} \leftrightharpoons \mathrm{BH}^{+} \mathrm{X}^{-}$. Mit diesem Reaktionsschema konnten die $\mathrm{p} K_{\mathrm{a}}$-Werte für protonierte Amine in Pyridin aus den Titrationskurven bestimmt werden, die mit einer geeichten Olaselektrode erhalten wurden. Für einige Polynitrophenole in Pyridin wurden bei der Titration dieser Verbindungen Beweise für das Auftreten von Homokonjugation gefunden. Aus den Titrationskurven wurden Homokonjugationskonstanten ermittelt.

\section{REFERENCES}

I L. M. Mukherjee. J. J. Kelly, W. Baranistzky and J. Sica, J. Phy.s. Chem., 72 (1968) 3410.

2 L. M. MUKher Jee and J. J. Kelly, J. Phy's. Chem., 71 (1967) 2348.

3 S. Bruckenstrin ANd I. M. Kolthoff, J. .1mer. Chem. Soc., 78 (1956) 10.

4 I. M. Kolthoff and S. Bruckenstein, J. Amer. Chem. Soc., 78 (1956) 1.

5 D. F. Detak, Compuler Programs for Chemistry. Vol. II, 1969, pp. 65-67.

Anal. Chim. Acta. 53 (1971) 39-46 